for terminal division cannot occur. We observed that mitomycin $c$-induced filaments did not divide nearly as readily as D-serine-induced filaments, although with pantoyl lactone or calcium chloride some division did occur. Pantoic acid was inactive.

Mitomycin $c$ apparently causes damage of cell wall or membrane. Supernatants from cultures grown in the presence of the antibiotic have a high $260 / 280 \mathrm{~m} \mu$ absorbance ratio as compared with uninoculated medium indicating leakage resulting from damage to the osmotic barrier. Lysis of cells occurs when mitomycin $c$ is added to exponentially growing cultures.

Mitomycin $c$ depolymerizes DNA in vivo when tested with Escherichia coli ${ }^{5}$. Much evidence exists that the mechanism of DNA breakdown in vivo is by means of the activation of a DNase, although in vitro activity of DNase from $E$. coli is not stimulated by mitomycin $c^{6}$. Reich et al..$^{5}$ state that magnesium is needed for an optimal depolymerization of DNA; in view of this it would be expected that increased magnesium concentrations would enhance, rather than diminish, mitomycin $c$ growth inhibition. It is possible that with this Erwinia species the optimum concentration for magnesium activation of DNase is exceeded at levels of magnesium which reverse growth inhibition. If this were true, the mechanism of growth inhibition by mitomycin $c$ would involve some factor other than activation of DNase. On the other hand, a certain concentration of magnesium (or other divalent cation) may serve to stabilize the DNA molecule, as it has been shown to do with RNA from yeast ${ }^{7}$, or tobacco mosaic virus, a calcium-magnesium co-ordination complex ${ }^{8}$.

The differential effects on growth and cell division by the various agents reported here indicate that the action of mitomycin $c$ on Erwinia cannot be explained completely in terms of scission of preformed DNA. The relationship of the known action of mitomyein $c$ on DNA to its effects with Erwinia obviously requires further scrutiny.

This investigation was supported by grant $G 9848$ from the U.S. National Science Foundation. We wish to thank Dr. R. D. Coghill, National Institutes of Health, for a gift of mitomycin $c$.

Mary M. Grula

E. A. Grula

Department of Bacteriology,

Oklahoma State University, Stillwater.

' Wakaki, S., Marumo, H., Tomioka, K., Shimizu, G., Kato, E. Kamada, H., Kudo, S., and Fugimoto, Y., Antibiot. and Chemother., 8, 228 (1958).

${ }^{2}$ Grula, E. A., J. Bact., 80, 375 (1960).

${ }^{3}$ Grula, E. A., and Grula, M. M., J. Bact., 83, 989 (1962).

1 Grula, M. M., and Grula, E. A., J. Bact. (in the press).

${ }^{5}$ Reich, E., Shatkin, A. J., and Tatum, E. L., Biochim. Biophys. Acta, 53, 132 (1961)

"Nakata, Y., Nakata, K., and Sakamoto, Y., Biochem. Biophys. Res. Comm., 6, 339 (1961).

' Maeda, A., J. Biochem. (Japan), 50, 377 (1961).

" Loring, H. S., Fujimoto, Y., and Tu, A. T., Virology, 16, 30 (1962).

\section{Taxonomy of the Fish Furunculosis Organism}

RECENTLY, Vickers and McClean ${ }^{1}$ described cases of fish furunculosis in Lough Neagh pollan, Coregonus pollan Thompson. They have named the organism isolated Bacillus salmonicida (Emmerich and Weibel). This is erroneous, as revealed by the description of characteristics given. Since the organism is Gramnegative, non-sporulating and able to ferment sugar to acid, it cannot belong to the genus Bacillus, which is defined as consisting of Gram-positive sporulating bacteria, obligate aerobe, with highly oxidative metabolism. The furunculosis organism was discovered by Emmerich and Weibel ${ }^{2}$ in 1894 and described as Bacterium salmonicida. This name has been in general use ${ }^{3-6}$ until in recent years when the organism was incorporated in the new genus Aero. monas Kluyver and Van $\mathrm{Niel}^{7,8}$.

The description of biochemical properties of the organism isolated by Vickers and McClean ${ }^{1}$ conforms with the official descriptions, except its lack of indole production. The regular strains should produce indole in broth cultures, but not hydrogen sulphide. However, although this is an important difference from the forma typica, it is not enough to separate the organism from the species Aeromonas salmonicida. belonging to the family Pseudomonadaceae of the Eubacteriales.

$$
\text { C. van DuiJn, Jun. }
$$

Prinses Margrietlaan 241, Zeist, Netherlands.

${ }^{1}$ Vickers, K. U., and McClean, R., Nature, 191, 930 (1961).

2 Emmerich and Weibel, Arch. Hygiene, 21 (1894).

${ }^{3}$ Hofer, B., Handbuch der Fischkrankheiten (Verlag Allg. Fisch.-Zttg. Munich, 1904).

4 Plehn, Marianne, Praktikum der Fischkrankheiten (Stuttgart, 1924). Schäperclaus. W., Fischkrankheiten, third ed. (Akademie-Verlag, Berlin, 1954).

- Duijn, C. van, jun., Diseases of Fishes (Water Life, London, 1956).

"Griffin, Ph. J., Trans. Amer. Fish. Soc., 83, 241 (1953).

${ }^{2}$ Duijn, C. van, jun., Fish as Food, edit. by Borgstrom, (., 2 (Acad. Press ; New York and London, 1962, in the press).

\section{VIROLOGY}

\section{Echo Virus Type 23 (Williamson) in Monkey Kidney Tissue Culture}

THe cytopathic effect produced by Echo virus type 23 in rhesus monkey kidney tissue culture has been unsatisfactory; where propagation in this system has been accomplished ${ }^{1,2}$, certain disadvantages made it necessary that an easier and less complicated method be devised for the regular detection of growth of this viral agent.

This report describes some improvements in the technique of the propagation of Echo 23 in rhesus monkey kidney tissue culture and its application in the optimal dilution (checker board) neutralization test.

Rhesus monkey (Macaca mulatta) kidney tissue culture tubes and bottles were prepared as previously described $^{3}$ in Eagle's growth medium with 5 per cent calf serum $(p H \mathbf{H} \cdot 0)$. After eight days growth and just before virus was inoculated growth medium was removed; the cells were washed twice with phosphatebuffered saline and 0.1 c.c. and 1.0 c.c. of $10^{1}$ dilution of Echo 23 (Williamson) was inoculated into tubes and milk dilution bottles respoctively. After $15-20 \mathrm{~min} 1.0$ c.c. and 10.0 c.c. of Sabin's maintenance medium consisting of 5 per cent lactalbumin hydrolysate in Earle's solution with 0.22 per cent sodium bicarbonate, $p \mathbf{H} 7 \cdot 5$ was added either to tubes ( 1.0 c.c.) or bottles $(10.0$ c.c.). Control tissue culture tubes and bottles were treated in the same way as infocted cultures, except that phosphato-buffered saline in the same volumes as those inoculated with tubes and bottles was added instead of virus.

In order to check the specificity of virus obtained by serial passage, an optimal dilution neutralization 